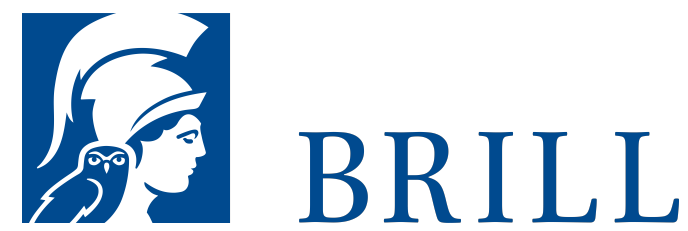

\title{
Die Katholische Aufklärung
}

Weltgeschichte einer Reformbewegung

Author: Ulrich L. Lehner

Lehner erzählt die vergessene Geschichte der reformfreudigen Katholiken des 18. Jahrhunderts in Nord- und Südamerika, Europa und Asien, die gegen Aberglaube kämpften und für die Ideale von Demokratie, Gleichheit der Geschlechter und den Wert der Naturwissenschaften einstanden.

In seiner Globalgeschichte zeigt der Autor auf, dass die Reformen des Konzils von Trient im 18. Jahrhundert eine Erneuerungsbewegung inspirierten, die in einen produktiven Austausch mit der Aufklärung trat. Nicht nur theologische Fragen wie das Verhältnis zu den Kirchen der Reformation wurden behandelt, sondern auch gesellschaftliche wie die Rechte der Frau, die Abschaffung der Sklaverei oder die Demokratisierung der Kirche. Erst die Französische Revolution von 1789 bereitete diesem Experiment katholischen Fortschritts ein Ende. Desillusioniert durch den Terror von Paris erblickte man nun in allem Aufklärerischen eine Gefahr - eine Haltung, die sich bis zum 2. Vatikanischen Konzil von 1962 hielt.

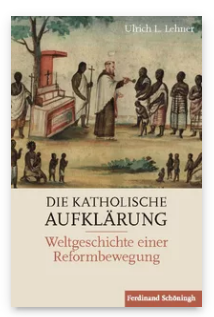

Pages: 271

Seiten

Language:

German

Subjects: Early

Modern History, History

Publisher: Brill | Schöningh

Paperback

Publication date: 11 Aug 2017

ISBN: 978-3506-78695-1 List price USD \$63.00 
Ulrich L. Lehner ist William K. Warren Professor an der University of Notre Dame, USA. Er ist Mitglied der European Academy of Sciences and

Arts und hat verschiedene Auszeichnungen und Forschungsstipendien erhalten

(Princeton Institute for Advanced Study, Earhart Foundation, Humboldt Stiftung,

Notre Dame Institute for Advanced Study).

Lehner

Ulrich L. Lehner

DIE

For more information see brill.com

Order information: Order online at brill.com +44330 3330049 | customerservices@brill.com Submission information: brill.com/authors

Titles published by Brill | Fink, Brill | mentis or Brill | Schöningh: +49(o)71 5413279216 | brill@brocom.de 